\title{
DRUŽINSKO IZOBRAŽEVANJE IN UČENJE V ISKANJU PRIKRITE HARMONIJE
}

Družinsko izobraževanje (family life education) ima na področju izobraževanja odraslih že dolgo tradicijo, še daljšo pa v okviru drugih dejavnosti. Poznamo nasvete o vzgoji otrok, $k i$ so bili del mašnih pridig, nasvete o higieni pri rojevanju, ki so bili del zdravniškega delovanja, nasvete o varni spolnosti itd. V zadnjih 50 letih lahko govorimo o hitrem razvoju profesionalnega področja: nastajajo študijski programi na univerzah $v$ ZDA in študijski predmeti na univerzah v Evropi, izhajajo strokovne knjige, spodbujene so raziskave in razvojni projekti, $k i$ podpirajo organizirano družinsko izobraževanje, kot je npr. projekt Learning as a Family. Razvija se mnogo novih oblik, ki vzpostavljajo okolje za učenje s pomočjo spletnih strani, e-pogovorov in svetovanj. Nastajajo šole za medsebojne odnose, komunikacijo $v$ družini, podporne skupine za pomoč pri soočanju z boleznijo $v$ družini ipd. Ljudi zanimajo različne teme, povezane z »družinskostjo«, kot npr. nega dojenčka, pomoč otrokom, partnerstvo, ki so »klasične teme«, povezane z gradnjo odnosnih dobrin in vzgojo otrok. Pojavlja pa se tudi zanimanje za novejše izzive, kot denimo staranje v dvoje, odnosi z vnuki, nasveti pri gradnji družinske hiše in najemanju posojil, pripravi zdravih obrokov za družino ... Družinsko izobraževanje ne vključuje le vsebin s področja vzgoje otrok, čeprav je to področje najstarejše in še vedno pomemben del družinskega izobraževanja, temveč tudi druge vsebine, ki podpirajo družinskost, npr. tiste, povezane z upravljanjem družinskih virov, ekonomskimi vidiki gospodinjstva, družinsko komunikacijo in dinamiko medosebnih odnosov, staranjem, religioznimi izzivi, medkulturnostjo.

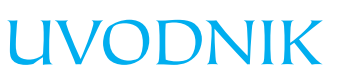

Družinsko izobraževanje ima v Evropi in Ameriki dolgo tradicijo. Že v 18. stoletju zasledimo prizadevanja, da bi z izobraževanjem izboljšali higieno, posebno ob porodih in pri negi dojenčkov. V 19. stoletju se že pojavijo priročniki za vzgojo otrok. Mnogo vsebin je bilo kasneje del programov v t. i. gospodinjskih šolah. Gentry (2005) piše o proučevanju družinskega izobraževanja v ZDA. Ugotovili so, da je bila na začet$k u$ večina ponudnic in udeleženk $v$ družinskem izobraževanju pripadnic (večina je bila žensk) srednjega sloja z evropskimi koreninami. Dandanes so udeleženke še vedno $v$ večini ženske, a se jim pridružujejo tudi moški. Pojavljajo se tudi posebne skupine, namenjene samo moškim.

Družinsko izobraževanje je organizirana vzgojno-izobraževalna dejavnost, ki odgovarja na izobraževalne potrebe odraslih - posameznikov, parov, družin $-v$ različnih obdobjih družinskega poteka. Sloni na vsebinah z različnih področij védenja in uporablja različne didaktične strategije. Poglavitni namen družinskega izobraževanja je okrepiti posameznikovo in družinsko blagostanje. Ob družinskem izobraževanju se razvija tudi model proučevanja in podpiranja družinskega učenja (family life learning), ki izhaja iz predpostavke, da je družina skupina, ki se uči v svojih vsakdanjih praksah.

Družina je v svojih pojavnih oblikah zelo vitalna, se prilagaja, spočenjajo se nove oblike družinskosti. Tako prilagodljiva je, da ji ne najdemo opredelitve, s katero bi se vsi strinjali, in tako vitalna je, da zelo pogosto beremo, da razpada, a se vedno znova vzpostavi v novih 
vezjih. V 60. in 70. letih prejšnjega stoletja so mnogi avtorji pisali o krizi družine (tudi zaradi novih spolnih praks, ki so se razvijale ob odkritju učinkovite kontracepcije). Tudi danes opazimo zapise o tem, da družina razpada. Statistični podatki kažejo, da upada število porok in narašča število ločitev, narašča število otrok, rojenih zunaj zakonske skupnosti. Psihiatri poročajo o novih »samostih«. Pravne in socialne službe se ukvarjajo z nasiljem $v$ družini. Vse to kaže na spremembe in tudi na to, da smo veliko bolj pozorni na negativne pojave, kot so nasilje, trpljenje, bolečina. Novonastalim potrebam se prilagajajo tudi izobraževalni programi, namenjeni specifičnim ciljnim skupinam, npr. ženskam v varnih hišah.

Veliko razprav je namenjenim novim oblikam družine: nastajajo enostarševske družine, razširjene družine, reorganizirane družine, istospolne družine, družine/partnerstva starejših ljudi. Če pogledamo v zgodovino, ugotovimo, da nobena oblika ni povsem nova. Enostarševske družine so ljudje že poznali, saj so ženske umirale ob porodih, moški v vojni, socialno starševstvo poznamo iz mnogih starih zgodb. Mogoče enostarševske družine niso trajale dlje časa, ker je revščina (med drugim) ljudi prisilila, da so si poiskali novega partnerja. Danes nastajajo enostarševske družine zaradi ločitev in ne zaradi smrti, pa tudi revščina (̌̌se) ne sili ljudi $v$ neželene partnerske povezave. Ne poznamo enega (normativnega) modela za starševstvo ali partnerstvo, temveč je mnogo modelov in tudi pri teh je vsaka skupnost ustvarjalka svojega šarma družinskosti. Kdo ne pozna zgodbe o ljubezni med Filemonom in Baucisom, dveh starcev, ki sta si želela, da bi umrla skupaj? In njuni telesi sta se spremenili $v$ hrast in lipo. Družinskost je mnogo več kot vzgoja otrok, zato bi potrebovali več raziskav, s katerimi bi ugotovili različne učinke različnih povezav $v$ različnih skupinah, diadah, mrežah in ob tem potrebe ljudi po znanju. Družino je treba vedno znova misliti in iskati možnosti za čim bolj kakovostno življenje. Izobraževanje in učenje je eden od načinov.

Družinsko izobraževanje se spreminja, ker se spreminja znanje, ki ga imamo ljudje, in ker se spreminja način skupnega bivanja. Ta številka Andragoških spoznanj je deloma namenjena razmisleku o učenju $v$ družini in izobraževanju za družino. Ob poimenovanju opazimo težave $s$ terminologijo, saj bi lahko uporabljali tudi besedne zveze, kot so: vzgoja za družinsko življenje, vzgoja in izobraževanje za družino, edukacija za družino. Kot ugotavljajo Matulčik (2004) in avtorji andragoškega posveta o strokovni terminologiji (Javrh, 2008), se ob hitro razvijajočem področju vzgoje in izobraževanja odraslih pojavljajo terminološki problemi vsaj na dveh ravneh. Najprej moramo tvoriti besede, da pojave sploh poimenujemo; nato pa nastane težava pri prevodih besed iz različnih jezikov. Še posebej nastajajo težave pri prenosu besed, ki imajo daljšo kulturno tradicijo in so oblikovale svoje kulturno pogojene pomene. Te ugotovitve veljajo tudi za področje andragogike družine, zato se ob široki uporabi angleškega jezika uveljavljata poimenovanji, zapisani $v$ naslovu.

Družinsko izobraževanje zajema izobraževalne dejavnosti od načrtovanja (dogodkov, programov, projektov) do evalvacije. Vključuje tudi raziskovanje področja, izobraževalnih potreb in razvijanje novih modelov. Sodobni pristopi uporabljajo različne didaktične strategije: od individualnega svetovanja do moderiranih internetnih klepetalnic, od bibliosvetovanja do priročnikov za samostojno učenje, tečajev, delavnic, množičnih predavanj, ki so lahko $v$ različnih realnih ali virtualnih okoljih. Načrtovalci izhajajo iz različnih teoretičnih modelov. Najbolj znane paradigme so instrumentalistič$n a$, interpretativna in emancipatorno-kritična. Teorije, ki so najbolj pogosto uporabljene, pa so: teorija sistemov, teorija življenjskega poteka, teorija socialnega učenja, teorija transformativnega učenja, teorija simboličnega 
interakcionizma, feministične teorije, ekološka teorija, antropološki pristopi, ki poudarjajo družino kot mikrokulturo (prim. Chibucos, Leite, 2005; Arcus, Schvaneveldt, Moss, 1993). Tudi nosilci izobraževanja so raznovrstni: centri za izobraževanje odraslih, svetovalni centri, šole, vrtci, cerkve, centri za socialno delo, lokalne skupnosti, muzeji, knjižnice, zdravstveni domovi, bolnišnice, društva. Družinsko izobraževanje povezuje znanje in izvajalce z različnih področij, zato pravimo, da je multidisciplinarno in multiprofesionalno.

Programi družinskega izobraževanja se hitro sirijo. V ZDA, denimo, narašča število programov za pomoč pri ločitvah (Divorce Education Programs), širijo se programi za družinsko pismenost (Family Literacy). Slednje so v Sloveniji razvili strokovnjaki z Andragoškega centra Slovenije pod imenom Beremo in pišemo skupaj. Krepitev družinskega izobraževanja najpogosteje povezujemo s spreminjanjem družine in družinskih vlog (novo očetovstvo, novo materinstvo), mobilnostjo prebivalstva in večkulturnostjo ter s staranjem prebivalstva. Inštitut Antona Trstenjaka je razvil poseben izobraževalni program Tečaj za družinske člane, ki oskrbujejo starega človeka. Družinsko izobraževanje namenja posebno pozornost družbeno občutljivim temam in stigmatiziranim skupinam. Eden od ciljev družinskega izobraževanja je razvoj rezilientnosti in opolnomočenje (empowerment) družin in tudi opolnomočenje posameznikov in posameznic $v$ različnih življenjskih obdobjih. Gibanje za svobodno izbiro in informiranost pred rojstvom otroka, med njim in po njem Naravni začetki je leta 2003 začelo izvajati program MamaZOFA, namenjen ženskam, ki se srečujejo z obporodnimi stiskami.

Poleg zanimanja za organizirano izobraževalno dejavnost se razvija raziskovanje in podpora za učenje $v$ vsakdanjem družinskem življenju. To je učenje, ki poteka nenamerno sredi družinske prakse. Interpretiramo ga z modeli biografskega učenja (West, 2009), izkustvenega učenja, modeli družinskih praks in priložnostnega učenja. Zamisel biografskega učenja upošteva vpetost posameznika in družine $v$ kulturno okolje in se ogne enostranskemu prepričanju, da lahko vsak posameznik povsem svobodno izbira svojo pot in odloča o svojem znanju in svojem spreminjanju. Poudarjeno je so-ustvarjanje družine, kar implicira tudi nove zmožnosti za oblikovanje odprtih prostorov dialoga in odgovornega ravnanja.

Za razvoj družinskega izobraževanja in učenja je potrebno medsebojno povezovanje različnih strok, za raziskovanje področja pa uporaba različnih teoretskih okvirov in raziskovalnih postopkov, ki osvetlijo družinsko dogajanje z raznovrstnih zornih kotov. Problemi na področju družinskega učenja in izobraževanja so zastavljeni transdisciplinarno, kar pomeni, da jih ne rešujemo v okviru ene discipline ali specifične akademske ali strokovne skupnosti. Raziskovalne in življenjske probleme rešujemo po načelu heterogenosti in prehodnosti znanja. Družinsko izobraževanje je področje skupnega delovanja, povezovanja institucij, strokovnjakov in disciplin, saj družinskih izzivov ne moremo reševati le z eno vrsto znanja in $v$ okviru ene stroke. $Z a$ vsak problem potrebujemo presečišče različnih znanj in veliko dialoških zmožnosti.

\section{Nives Ličen}

\section{LITERATURA}

Arcus, M., Schvaneveldt, J. D., Moss, J. J. (ur.) (1993). Handbook of Family Life Education. Vol 1, Vol 2. Newbury Park, London, New Delhi: Sage.

Chibucos, T. R., Leite, R. W. (2005). Readings in Family Theory. Thousand Oaks, London, New Delhi: Sage.

Duncan, F. S., Goddard, H. W. (2005). Family Life Education. Thousand Oaks: Sage.

Javrh, P. (ur.) (2008). Vseživljenjsko učenje in strokovno izrazje. Ljubljana: Pedagoški inštitut. 
Gentry, D. B. (2005). »Contemporary Family Life Education«. V: Coleman, M., Ganong, L. (ur.), Handbook of Conteporary Families. Thousand Oaks, London, New Delhi: Sage, 538-554.

Matulčik, J. (2004). Teórie výchovy a vzdelávania dospelých v zahraniči. Bratislava: Akademie vzdelavania Bratislava.

West, L. (2009). »Lifelong learning and the family: an auto/biographical imagination «. V: Jarvis, P. (ur.), The Routledge International Handbook of Lifelong Learning. London, New York: Routledge, 67-79. 